\title{
Using Digital Photography to Examine Grazing in Montane Meadows
}

\author{
Susan K. McIlroy, ${ }^{1}$ Barbara H. Allen-Diaz, ${ }^{2}$ and Alexander C. Berg ${ }^{3}$
}

Authors are ${ }^{1}$ Ecologist, USGS Forest and Rangeland Ecosystem Science Center, Snake River Field Station, 970 Lusk Street, Boise, ID 83706, USA;

${ }^{2}$ Professor, Department of Environmental Science, Policy, and Management, 130 Mulford Hall \#3114, University of California, Berkeley, CA 94720, USA; and ${ }^{3}$ Assistant Professor, Computer Science Department, 1440 Computer Science, Stony Brook University, Stony Brook, NY 11794, USA.

\begin{abstract}
Cattle (Bos taurus) numbers on national forests are allocated based on allotment grazing capacity, but spatial patterns of timing and density at smaller scales are difficult to assess. However, it is often in meadows or riparian areas that grazing may affect hydrology, biodiversity, and other important ecosystem characteristics. To explore real-time animal presence in montane meadows we distributed 18 digital cameras across nine sites in the Sierra National Forest, California. Our objectives were to document seasonal and diurnal presence of both cattle and mule deer (Odocoileus hemionus), identify the effects of three fencing treatments on animal distribution, and test digital photography as a tool for documenting cattle presence. We recorded 409399 images during daylight hours for two grazing seasons, and we identified 5084 and 24482 cattle "marks" (instances of animal occurrence) in 2006 and 2007, respectively. Deer presence was much lower, with 331 marks in 2006 and 598 in 2007. Morning cattle presence was highest before 0800 hours both years $(13.7 \%$ and $15.4 \%$ of total marks for 2006 and 2007, respectively). Marks decreased until 1100 hours and then increased around 1400 hours and remained relatively stable until 1900 hours. Marks then rose precipitously, with $>20 \%$ of total marks recorded after 1900 hours both years. Deer presence was less than $10 \%$ per hour until 1800 hours, when $>20 \%$ of total marks were recorded after this time both years. Among treatments, cattle marks were highest outside fences at partially fenced meadows, and deer were highest within completely fenced meadows. Our experience suggests that cameras are not viable tools for meadow monitoring due to variation captured within meadows and the time and effort involved in image processing and review.
\end{abstract}

\section{Resumen}

La cantidad de ganado (Bos taurus) se pastorea en los bosques nacionales se basa en la capacidad de carga de cada una de las áreas, pero los patrones espaciales de distribución y el tiempo así como la densidad en escalas más pequeñas son difíciles de determinar. Sin embargo, es a menudo que en zonas ribereñas o prados que el pastoreo pueda afectar la hidrología, la biodiversidad, y otras importantes características de los ecosistemas. Para explorar la presencia animal en tiempo real en un prado distribuimos 18 cámaras fotográficas digitales a través de nueve sitios en Sierra National Forest, California. Nuestros objetivos fueron el documentar la presencia estacional y diurna tanto del ganado como el venado pardo (Odocoileus hemionus), e identificar el efecto de tres tratamientos de cercos en la distribución de los animales, y experimentar la fotografía digital como herramienta para documentar la presencia del ganado. Registramos un total de 409399 imágenes durante las horas con luz, durante dos estaciones de pastoreo, e identificamos 5084 y 24482 "marcas" del ganado (ocasiones donde había presencia animal) en 2006 y 2007; respectivamente. La presencia de los venados fue mucho más baja, con 331 marcas en 2006 y 598 en 2007. La presencia del ganado durante la mañana fue la más alta antes de las $8: 00$ horas en ambos años $(13.7 \%$ y $15.4 \%$ del total de las marcas para 2006 y 2007, respectivamente). Las marcas disminuyeron hasta las 11:00 horas y después se incrementaron alrededor de las 14:00 horas y permanecieron relativamente estables hasta las 19:00 horas. Después las marcas aumentaron precitadamente, con $>20 \%$ del total de marcas registradas después de 19:00 horas en ambos años. La presencia de los venados fue menor del 10\% por hora hasta las 18:00 horas, cuando $>20 \%$ del total de las marcas se registraron después de esta hora en los dos años. Entre tratamientos, las marcas del ganado fueron mayores fuera de las aéreas parcialmente cercadas y la de los venados fueron mayores dentro de las áreas totalmente cercadas. Nuestra experiencia sugiere que las cámaras fotográficas no son herramientas viables para el monitoreo de los prados debido a la variación capturada dentro de las áreas y el tiempo y esfuerzo implicado en el proceso de la revisión de la imágenes.

Key Words: cattle management, digital photography, diurnal grazing, fencing treatments, mule deer

\footnotetext{
Research was funded by the USDA Forest Service, Region 5.

At the time of research, Mcllroy was Graduate Student Researcher, Department of Environmental

Science, Policy, and Management, University of California, Berkeley, CA 94720, USA.

Correspondence: Susan Mcllroy, USGS Forest and Rangeland Ecosystem Science Center,

Snake River Field Station, 970 Lusk Street, Boise, ID 83706, USA. Email: smcilroy@usgs.gov

Manuscript received 1 October 2009; manuscript accepted 17 October 2010.
}

\section{INTRODUCTION}

Montane meadows serve a critical role in forested landscapes. They are areas of high biodiversity that provide habitat for many native and rare species (Ratliff 1985), act as buffers for nutrients and water (Mitsch and Gosselink 1993), and serve as 
headwaters to streams and rivers important for agriculture and human use (Field et al. 1999). They also produce forage for grazing animals, and cattle (Bos taurus) preferentially select meadows due to favorable biotic (e.g., forage quality and quantity, plant composition, and plant morphology) and abiotic conditions (e.g., slope, distance to water, topography; Roath and Krueger 1982; Bailey et al. 1996; George et al. 2007). For example, a study on a montane cattle allotment in the Blue Mountains of Oregon concluded that $80 \%$ of forage consumed by cattle occurred in meadows, which comprised only $1.9 \%$ of the total area available to animals (Roath and Krueger 1982). Wildlife such as mule deer (Odocoileus hemionus) also prefer meadow habitat (Loft 1988; Loomis et al. 1991), and research has shown competition between cattle and deer for forage and habitat (e.g., McMahan and Ramsey 1965; Stover 1985; Kie et al. 1991; Loft et al. 1991).

Due to their importance within forested ecosystems, conserving meadows is often a priority for national forest managers. In some cases managers have chosen to completely fence areas in an effort to preserve habitat for native, threatened, or endangered species and/or protect sites that are being restored (Sanders and Flett 1989; Kattleman and Embury 1996; George et al. 2007). However, fencing involves an expensive initial investment, potential repeated costs associated with maintenance, and loss of forage for grazing animals (Gillen et al. 1985; Kie and Myler 1987). If cattle are present, fencing can also concentrate animals into smaller areas, causing heavy utilization of the remaining available forage (Roath and Krueger 1982). Additionally, preventing grazing may not lead to achieving management objectives, as in many cases cattle have been shown to increase biodiversity and benefit ecosystem processes (e.g., Robins and Vollmar 2002; Hayes and Holl 2003; Hickman et al. 2004).

Monitoring cattle use of montane meadows is challenging for a number of reasons. First, grazing allotments are the unit at which animals are allocated across national forest lands, and each allotment may cover thousands of hectares. The number of cow/calf pairs (e.g., animal units) and timing of on/off dates are recorded at the allotment scale, but these data do not necessarily correspond to the distribution of animals within the allotment and therefore do not address potential animal effects at smaller scales. Second, meadows are often remote, and visiting sites to measure late season utilization and/or determine stubble height generally involves much time and effort for managers. Last, meadows are remarkably diverse ecosystems, with factors such as uneven water distribution and heterogeneous plant composition making monitoring difficult even within one meadow (Gillen et al. 1984).

To study animal behavior and the effects of herbivory on plants, researchers have used a suite of tools such as vibracorders (specially designed clocks affixed to cows that measure movements), video footage, digital cameras, Geographic Information Systems, and Geographic Positioning Systems (Gillen et al. 1985; Harris et al. 2002; George 2003; Parsons et al. 2003; Boyd and Svejcar 2005; Boyd et al. 2006). For example, Parsons et al. (2003) used vibracorders in northeastern Oregon to determine that cattle were consistently observed farther from a stream earlier in the grazing season when compared to later in the summer. Gillen et al. (1985) used movie cameras to determine cattle use under continuous and deferred-rotation grazing systems on two meadows in Oregon and they found at least one cow present per day $\sim 60 \%$ of the time with both systems. Further advances have been made specifically in wildlife research, with remote-triggered photography and video recording used to monitor wildlife occurrence ( $\mathrm{Ng}$ et al. 2004), estimate population abundance (Koerth and Kroll 2000), study animal activity and behavior (Hooker et al. 2002), and even monitor aquatic environments (Lopez and Silvy 1999). Yasuda and Kawakami (2002) and Locke et al. (2005) improved upon remote monitoring by using web-based systems to transfer real-time data to a computer for immediate review.

Our goal was to use digital cameras to study animal presence and distribution on montane meadows. We addressed the following objectives: 1) document seasonal and diurnal patterns of cattle and deer presence in meadows, 2) identify the effects of fencing treatments on cattle and deer distribution, and 3 ) test digital photography as a tool for monitoring cattle. We hypothesized that partially enclosing meadows would concentrate cattle grazing in remaining areas and that deer presence would increase inside fenced areas where cattle were excluded due to decreased competition for forage. We thought that cameras would be promising tools for meadow monitoring, and we provide a discussion of the effectiveness of cameras for this purpose.

\section{METHODS}

\section{Study Area}

The study area included nine meadows on the western slope of the Sierra Nevada Range, about $100 \mathrm{~km}$ northeast of Fresno, California. All meadows were located within three active grazing allotments on the Sierra National Forest (Fig. 1). Allotments ranged in size from 21783 to 26659 ha, and permittees turned out 200, 220, and 235 cow/calf pairs per allotment both years (Table 1). Study meadows ranged from 1.2 to 7.7 ha in size and 2108 to $2655 \mathrm{~m}$ in elevation. Cattle were present in the meadows from 9 July to 7 September 2006 and 14 June to 7 September 2007; grazing began earlier in 2007 due to a much lighter snowpack. Prominent meadow vegetation included Eleocharis pauciflora, Carex nebrascensis, Carex jonesii, Juncus balticus, Juncus oxymeris, Polygonum bistortoides, and Aster alpigenus (Hickman 1993). Average yearly minimum and maximum air temperatures are $-13^{\circ} \mathrm{C}$ and $22^{\circ} \mathrm{C}$. Precipitation across meadows averages $108 \mathrm{~cm}$ annually, with 2006 higher than average $(132 \mathrm{~cm})$ and 2007 much below average (56 cm; Daly et al. 2002).

\section{Study Design and Data Analysis}

We used a randomized complete block design to assign each of nine meadows one of three treatments. The three allotments are blocks, and each block had a Fence Whole Meadow (FWM), Fence Wet Area (FWA), or Standard Grazing (SG) treatment applied. We further separated the FWA treatment into inside and outside the fenced area to identify changes in cattle and deer distribution with partial meadow fencing. Therefore we report FWA_In and FWA_Out separately. The FWA treatment was designed to test the effect of restricting cattle grazing in sensitive habitat such as wet areas but permitting it in other 


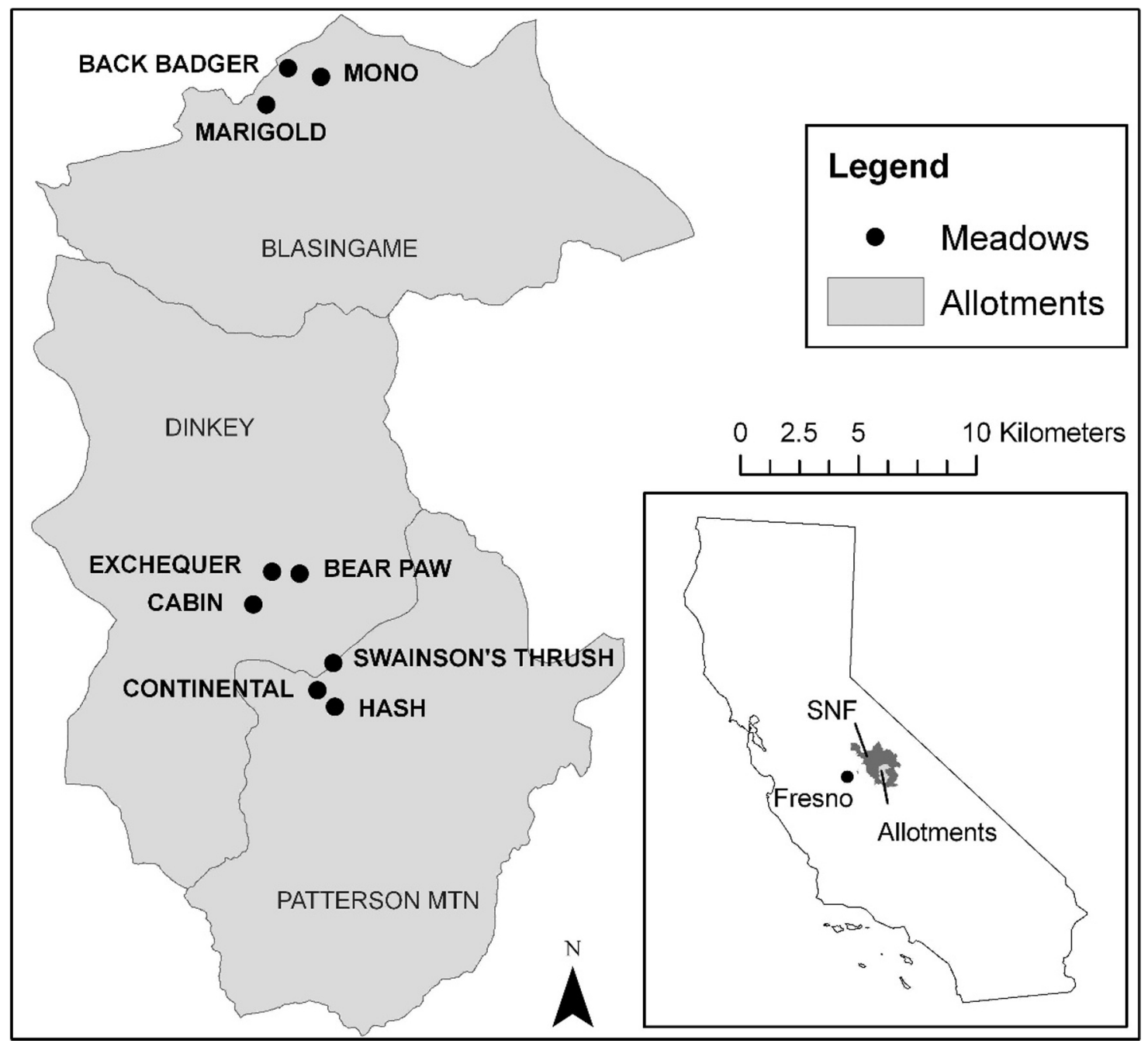

Figure 1. Location of the three grazing allotments and nine study meadows.

parts of a meadow. Forest Service biologists and managers designated the area to be fenced for the FWA sites. FWM sites were completely enclosed, with fences constructed in the surrounding forest. The SG meadows had grazing under current US Forest Service standards and guidelines, which is no more than $40 \%$ use (USDA Forest Service 2004). We estimated meadow size and unfenced area (ha) in ArcGIS (2006) using aerial imagery from the National Agriculture Inventory Program (acquired summer 2005).

We distributed 18 digital cameras (Reconyx, PM35 model, $640 \times 480$ pixels, 1 byte grayscale, Reconyx, Inc. Holmen, WI) across the nine meadows for the summer grazing season both years (Table 2). Cameras were installed 3 to $4 \mathrm{~m}$ high in meadow-edge trees with few branches and no neighboring trees that obstructed the camera views. We placed cameras in the same trees in 2006 and 2007, but the meadow area covered was not the same because camera height and tilt differed between years. We estimated the area captured per camera by using a printed image from each camera and walking the image perimeter with a GPS device (Garmin eTrex, 3-m accuracy WAAS enabled, Garmin Inc., Chicago, IL). We then used ArcGIS to calculate area (ha) captured by each camera using the perimeter points. We did not place or retrieve all cameras at the same time in 2006, but recording in 2007 was more

Table 1. Summary of allotment data.

\begin{tabular}{lccc}
\hline & Blasingame & Dinkey Creek & Patterson Mtn. \\
\hline Allotment area (ha) & 21783 & 26659 & 21820 \\
Cow/calf pairs & 235 & 220 & 200 \\
Total number of meadows & 238 & 250 & 162 \\
Total meadow area (ha) & 763.21 & 349.79 & 241.22 \\
Mean meadow area $( \pm \mathrm{SE})$ & $3.21(0.59)$ & $1.40(0.16)$ & $1.49(0.20)$ \\
Study meadows percent of total meadows & $3.50 \%$ & $1.31 \%$ & $1.11 \%$ \\
\hline
\end{tabular}


Table 2. Camera distribution per meadow.

\begin{tabular}{llc}
\hline \multicolumn{1}{c}{ Meadow } & \multicolumn{1}{c}{ Allotment } & Cameras \\
\hline $\begin{array}{l}\text { Fence whole meadow } \\
\text { Bear Paw }\end{array}$ & Dinkey Creek & 1 \\
Mono & Blasingame & 1 \\
Swainson's Thrush & Patterson Mountain & 1 \\
Fence wet areas & & \\
Back Badger & Blasingame & 2 \\
Continental & Patterson Mountain & 2 \\
Exchequer & Dinkey Creek & 2 \\
Standard grazing & & \\
Cabin & Dinkey Creek & 3 \\
Hash & Patterson Mountain & 3 \\
Marigold & Blasingame & 3 \\
\hline
\end{tabular}

consistent across meadows. Due to differences in image area and days recorded among cameras, we normalized all data by mean "marks" (instances of animal occurrence) per day per ha (MMDH). For example, we report a camera that recorded 200 marks over 100 days in an area of 0.1 ha as $20 \mathrm{MMDH}$. We programmed cameras to record an image every five minutes during daylight hours. The number of daylight hours varied depending on time of year and meadow, but cameras were generally able to record clear images starting at 0600 hours and continuing to between 2000 to 2100 hours. Date, time and temperature were recorded with each image.

To identify cattle and deer, we first explored using image recognition software, which identifies and counts objects (e.g., animals). However, we were unable to use an automated program for this project because the large area included in some images made animals farther from the camera increasingly difficult to distinguish from shadows. We were concerned about false-negative data, or not marking animals when they were present, so we manually marked images to decrease our error rate. We used Matlab (2005) computing language to develop marking and counting tools and to increase data review efficiency. Each image was evaluated once in the program, and animals were marked. In 2006 we conducted the entire review process a second time to check our initial markings, and the combined error rate of false negatives and false positives was less than $5 \%$. We therefore chose only a subset of 2007 data to re-review, and again the error rate was less than $5 \%$. Number of cows, number of deer, date, and time for each image containing at least one mark were recorded. All data are reported in terms of marks, and the same animal may be present in successive frames. All data are summarized by treatment, and we used the Wilcoxon rank-sum test $(P<0.05$; SPLUS 2005) to analyze the influence of specific fencing treatments on cattle and deer.

\section{RESULTS}

\section{Seasonal Grazing}

Each camera $(n=18)$ recorded an average of 150 images per day, with 151192 total images in 2006 and 258207 in 2007.
Cameras recorded from 9 July to 7 September 2006, with $1.6 \%$ $( \pm 0.0 \mathrm{SE})$ of total images captured each day. There were 901 total camera days in 2006 and 180 days $(20.0 \%)$ with at least one cow present. There were 5084 total cow marks with an average of 36.8 ( $\pm 12.4 \mathrm{SE}$ ) MMDH (Table 3 ). We documented trespass within the fenced area at Back Badger (FWA; 6.2 $\mathrm{MMDH})$, with no other cattle recorded within fences.

In 2007, cameras recorded from 14 June to 7 September, with $1.2 \%$ ( $\pm 0.01 \mathrm{SE}$ ) of total images captured each day. Due to more continuous coverage and a longer grazing season, cameras recorded 1504 total days with 418 days $(27.8 \%)$ having at least one cow present. The total number of cow marks for the 2007 season was 24 482, and there was an average of 76.1 ( $\pm 19.3 \mathrm{SE}) \mathrm{MMDH}$ (Table 4).

MMDH were dispersed throughout both seasons (Table 5) except for Back Badger (FWA), where all marks were recorded by 28 July the first year, and $80 \%$ of marks were recorded by 27 June the second year. Inside fenced areas, cameras recorded trespass at a few meadows in 2007. We again recorded cattle within the fence at Back Badger (FWA; 22.5 MMDH). Bear Paw (FWM) had 18.2 MMDH, with all marks occurring from 14 August to 16 August when cows breached the fence. Mono (FWM) also had one mark and signs of grazing within the fence, but the camera did not record more than one trespass incident.

There were 331 total deer marks in 2006 with an average of 1.1 ( $\pm 0.3 \mathrm{SE}$ ) MMDH. Marks increased in 2007 to 598 with an average of $1.4( \pm 0.8 \mathrm{SE}) \mathrm{MMDH}$ (Table 6$)$. Deer grazing was dispersed throughout the season in 2006 and 2007 and was not similar between years. The majority of marks were also at a few meadows, with $26.1 \%$ of total MMDH at Mono (FWM) in 2006 and 47.6\% of MMDH at Bear Paw (FWM) in 2007.

\section{Diurnal Presence}

We partitioned daylight marks per hour to analyze patterns of cattle presence (Fig. 2). This roughly equaled 14 to 15 hours of review per day per camera, but again this varied depending on timing of sunrise and sunset. All cameras with marks were included in the analysis ( $n=12$ for 2006 and $n=16$ for 2007). Morning cattle presence was highest from 0700 to 0800 hours (7.8\% of total marks) in 2006, and in 2007 it was highest from 0600 to 0700 hours $(10.5 \%$ of total marks), with both years decreasing to their lowest levels from 0800 to 1100 hours. Marks then increased until 1400 to 1500 hours, and they remained relatively stable until 1900 hours. Cattle presence then rose precipitously, with $21.6 \%$ and $23.3 \%$ of marks recorded after 1900 hours for 2006 and 2007, respectively. The decrease in marks between 2000 and 2100 hours is likely due to light limitations and is not reflective of a decrease in grazing during that time.

Diurnal presence for deer was also similar between years (Fig. 3). In 2006, 9.1\% of total marks were recorded from 0600 to 0700 hours and remained below $10 \%$ until 1800 to 1900 hours, when they continued increasing until a high of $27.8 \%$ from 2000 to 2100 hours. In 2007, marks were also less than $10 \%$ until 1800 to 1900 hours, when they rose dramatically from 1900 to 2000 hours and $48.5 \%$ of total marks were recorded. Marks then decreased to $27.9 \%$ from 2000 to 2100 hours, but again, that decrease is likely due to lack of light during that time. 
Table 3. Summary of 2006 cattle marks, camera days, and camera and meadow areas. MMDH was calculated by dividing total marks by camera days and then by camera area. Meadow covered is the percent of total meadow area that was captured by cameras.

\begin{tabular}{|c|c|c|c|c|c|c|c|}
\hline 2006 cameras & $\begin{array}{l}\text { Total } \\
\text { marks }\end{array}$ & $\begin{array}{l}\text { Camera } \\
\text { days }\end{array}$ & $\begin{array}{l}\text { Mean marks } \\
\text { per day }\end{array}$ & $\begin{array}{c}\text { Camera } \\
\text { area (ha) }\end{array}$ & $\begin{array}{l}\text { Mean marks per day } \\
\text { per ha (MMDH) }\end{array}$ & $\begin{array}{l}\text { Meadow } \\
\text { area }(\text { ha })^{2}\end{array}$ & $\begin{array}{c}\text { Meadow } \\
\text { covered (\%) }\end{array}$ \\
\hline \multicolumn{8}{|l|}{ Fence wet area ${ }^{1}$} \\
\hline Back Badger_1 (inside) & 72 & 61 & 1.2 & 0.2 & 6.2 & 1.3 & 20.2 \\
\hline Back Badger_1 (outside) & 1402 & 61 & 23.0 & 0.2 & 121.0 & & \\
\hline Back Badger_2 (outside) & 41 & 22 & 1.9 & 0.0 & 46.6 & $0.4^{\star}$ & \\
\hline Continental_1 (inside) & 0 & 61 & 0.0 & 0.2 & 0.0 & 4.0 & 8.9 \\
\hline Continental_2 (outside) & 48 & 27 & 1.8 & 0.1 & 13.7 & $2.3^{\star}$ & \\
\hline Exchequer_1 (inside) & 0 & 61 & 0.0 & 0.3 & 0.0 & 5.8 & 6.1 \\
\hline Exchequer_2 (outside) & 468 & 48 & 9.8 & 0.1 & 195.0 & $0.7^{\star}$ & \\
\hline \multicolumn{8}{|l|}{ Fence whole meadow } \\
\hline Bear Paw & 0 & 61 & 0.0 & 0.4 & 0.0 & 1.2 & 28.7 \\
\hline Mono & 0 & 61 & 0.0 & 0.4 & 0.0 & 3.0 & 11.7 \\
\hline Swainson's Thrush & 0 & 61 & 0.0 & 0.2 & 0.0 & 0.7 & 32.4 \\
\hline \multicolumn{8}{|l|}{ Standard grazing } \\
\hline Cabin_1 & 45 & 37 & 1.2 & 0.1 & 17.4 & 1.8 & 19.0 \\
\hline Cabin_2 & 430 & 61 & 7.0 & 0.1 & 58.7 & & \\
\hline Cabin_3 & 485 & 61 & 8.0 & 0.2 & 53.0 & & \\
\hline Hash_1 & 371 & 46 & 8.1 & 0.1 & 100.8 & 2.0 & 43.4 \\
\hline Hash_2 & 700 & 38 & 18.4 & 0.4 & 48.5 & & \\
\hline Hash_3 & 1022 & 61 & 16.8 & 0.4 & 39.9 & & \\
\hline Marigold_1 & 0 & 36 & 0.0 & 0.3 & 0.0 & 7.8 & 8.3 \\
\hline Marigold_2 & 0 & 26 & 0.0 & 0.1 & 0.0 & & \\
\hline Marigold_3 & 0 & 54 & 0.0 & 0.3 & 0.0 & & \\
\hline
\end{tabular}

${ }^{1}$ Note that Back Badger_1 recorded images inside and outside the fenced area. Continental_1 and Exchequer_1 recorded only inside the fenced area.

${ }^{2}$ Asterisks indicate area of unfenced meadow.

\section{Fencing Treatments}

Cattle marks varied greatly among treatments (Table 7). MMDH ranged from $3.0( \pm 3.0 \mathrm{SE})$ in the FWM treatment to $114.6( \pm 27.2 \mathrm{SE})$ in the FWA_Out treatment. There was also variation within treatments. For example, SG meadows $(n=9)$ ranged from 0 to $100.8 \mathrm{MMDH}$ in 2006 and 0 to 234.9 in 2007 (Tables 3 and 4). Additionally, two of the FWA_In meadows had no marks both years but Back Badger_In had 6.2 and 22.5 MMDH in 2006 and 2007, respectively. Meadows with more than one camera also varied, such as Hash (SG) in 2007, where there were over three times more MMDH at Cameras 2 and 3 compared to Camera 1. We did not find a significant difference in $\mathrm{MMDH}$ for cattle between FWA_Out $(n=8)$ and SG $(n=18)$ sites $(Z=1.72, P=0.09)$.

Deer marks ranged from 0.6 $\mathrm{MMDH}( \pm 0.2 \mathrm{SE})$ in the FWA_In treatment to $3.8 \mathrm{MMDH}( \pm 2.0 \mathrm{SE})$ in the FWM treatment (Table 7). As with cattle, there was significant variation within and among treatments for deer. For example, in 2007 Bear Paw (FWM) had 13.0 MMDH compared to only 0.2 and 1.1 MMDH for Mono and Swainson's Thrush, respectively. Across meadows there was also marked variation between years, but there was no consistent pattern of these differences among meadows.

To determine the effects of fencing specifically on deer, we compared fenced (2.2 MMDH $\pm 1.1 \mathrm{SE} ; n=12)$ and unfenced (0.9 $\mathrm{MMDH} \pm 0.6 \mathrm{SE} ; n=26)$ meadow areas and found no significant difference between the two $(\mathrm{Z}=1.74, P=0.08)$.

\section{Scaling Marks and Correlations with Utilization}

We conducted two analyses to evaluate the effectiveness of cameras for meadow monitoring. First, we explored scaling data to larger areas using linear regression (SPLUS) to determine if image size and MMDH were correlated. A similar relationship exists in vegetation sampling, where frequency (presence/absence) is dependent on plot size (Mueller-Dombois and Ellenberg 1974). We found no correlation between area covered by each camera and MMDH $\left(R^{2}=0.04, P=0.2\right)$. Gillen et al. (1985) also found no relationship between area and the number of cows in a movie frame.

To further test the effectiveness of cameras for monitoring meadows we regressed $\mathrm{MMDH}$ with late season utilization values. We wanted to determine if there was a relationship between the two; if there was, then cameras could potentially be an additional proxy for measuring cattle use in meadows. Using utilization plot data from another study conducted at the same sites (McIlroy 2008), we first constrained utilization data to plots within images and then conducted a second regression using averaged plot data for each meadow. We then compared these values to total MMDH per image and MMDH per meadow, respectively. Using linear regression we found correlations between utilization and marks at both the image $\left(R^{2}=0.38\right.$, $P<0.05)$ and meadow $\left(R^{2}=0.47, P<0.05\right)$ scales. A correlation would be expected, as the number of cows present presumably influences the amount of grazing that occurs. However, the variation we observed among cameras within meadows makes these correlations less useful. 
Table 4. Summary of 2007 cattle marks, camera days, and camera and meadow areas. MMDH was calculated by dividing total marks by camera days and then by camera area. Meadow covered is the percent of total meadow area that was captured by cameras.

\begin{tabular}{|c|c|c|c|c|c|c|c|}
\hline 2007 Cameras & $\begin{array}{l}\text { Total } \\
\text { marks }\end{array}$ & $\begin{array}{c}\text { Camera } \\
\text { days }\end{array}$ & $\begin{array}{c}\text { Mean marks } \\
\text { per day }\end{array}$ & $\begin{array}{l}\text { Camera } \\
\text { area (ha) }\end{array}$ & $\begin{array}{c}\text { Mean marks per day } \\
\text { per ha (MMDH) }\end{array}$ & $\begin{array}{c}\text { Meadow } \\
\text { area }(\text { ha) })^{2}\end{array}$ & $\begin{array}{c}\text { Meadow } \\
\text { covered (\%) }\end{array}$ \\
\hline \multicolumn{8}{|l|}{ Fence wet area ${ }^{1}$} \\
\hline Back Badger_1 (inside) & 475 & 88 & 5.4 & 0.2 & 22.5 & 1.3 & 42.4 \\
\hline Back Badger_1 (outside) & 2303 & 88 & 26.2 & 0.2 & 109.0 & & \\
\hline Back Badger_2 (outside) & 3488 & 49 & 71.2 & 0.3 & 245.5 & $0.4^{*}$ & \\
\hline Continental_1 (inside) & 0 & 87 & 0.0 & 0.3 & 0.0 & 4.0 & 8.9 \\
\hline Continental_2 (outside) & 429 & 87 & 4.9 & 0.1 & 61.6 & $2.3^{*}$ & \\
\hline Exchequer_1 (inside) & 0 & 89 & 0.0 & 0.3 & 0.0 & 5.8 & 9.2 \\
\hline Exchequer_2 (outside) & 2656 & 89 & 29.8 & 0.2 & 124.3 & $0.7^{*}$ & \\
\hline \multicolumn{8}{|l|}{ Fence whole meadow } \\
\hline Bear Paw & 616 & 87 & 7.1 & 0.4 & 18.2 & 1.2 & 32.0 \\
\hline Mono & 1 & 88 & 0.0 & 0.4 & 0.0 & 3.0 & 12.0 \\
\hline Swainson's Thrush & 0 & 87 & 0.0 & 0.2 & 0.0 & 0.7 & 25.7 \\
\hline \multicolumn{8}{|l|}{ Standard grazing } \\
\hline Cabin_1 & 891 & 89 & 10.0 & 0.1 & 100.1 & 1.8 & 24.0 \\
\hline Cabin_2 & 1798 & 89 & 20.2 & 0.1 & 144.3 & & \\
\hline Cabin_3 & 748 & 49 & 15.3 & 0.2 & 80.3 & & \\
\hline Hash_1 & 497 & 87 & 5.7 & 0.1 & 57.1 & 2.0 & 25.0 \\
\hline Hash_2 & 4831 & 87 & 55.5 & 0.3 & 205.7 & & \\
\hline Hash_3 & 4701 & 87 & 54.0 & 0.2 & 234.9 & & \\
\hline Marigold_1 & 627 & 88 & 7.1 & 0.4 & 19.3 & 7.8 & 9.6 \\
\hline Marigold_2 & 81 & 88 & 0.9 & 0.1 & 0.1 & & \\
\hline Marigold_3 & 340 & 88 & 3.9 & 0.2 & 16.8 & & \\
\hline
\end{tabular}

${ }^{1}$ Note that Back Badger_1 recorded images inside and outside the fenced area. Continental_1 and Exchequer_1 recorded only inside the fenced area.

${ }^{2}$ Asterisks indicate area of unfenced meadow.

Table 5. Seasonal distribution of cattle and deer marks. Results start with the first day that cameras were recording each season and are reported in two-week time periods.

\begin{tabular}{|c|c|c|c|c|}
\hline & \multicolumn{2}{|c|}{ Cattle } & \multicolumn{2}{|c|}{ Deer } \\
\hline & $\begin{array}{c}\text { Total } \\
\text { marks }\end{array}$ & $\begin{array}{l}\text { Percent } \\
\text { of total }\end{array}$ & $\begin{array}{l}\text { Total } \\
\text { marks }\end{array}$ & $\begin{array}{l}\text { Percent } \\
\text { of total }\end{array}$ \\
\hline \multicolumn{5}{|l|}{2006} \\
\hline 9 July-23 July & 1175 & 31.7 & 24 & 14.8 \\
\hline 24 July-7 August & 1177 & 31.7 & 76 & 46.9 \\
\hline 8 August-21 August & 810 & 21.8 & 36 & 22.2 \\
\hline 22 August-4 September & 535 & 14.4 & 26 & 16.0 \\
\hline 5 September-7 September ${ }^{1}$ & 13 & 0.4 & 0 & 0.0 \\
\hline \multicolumn{5}{|l|}{2007} \\
\hline 14 June-28 June & 4619 & 28.6 & 0 & 0.0 \\
\hline 29 June-13 July & 2140 & 13.2 & 12 & 9.4 \\
\hline 14 July-28 July & 3245 & 20.1 & 8 & 6.3 \\
\hline 29 July-12 August & 1896 & 11.7 & 19 & 15.0 \\
\hline 13 August-27 August & 1320 & 8.2 & 19 & 15.0 \\
\hline 28 August-7 September ${ }^{1}$ & 2977 & 18.4 & 69 & 54.3 \\
\hline
\end{tabular}

${ }^{1}$ Note less than two weeks.

\section{DISCUSSION}

\section{Animal Presence}

Research has shown that cattle disproportionately graze and rest in meadows due to higher forage quality and quantity, proximity to water, and a more favorable microclimate (Bryant 1982; Roath and Krueger 1982; Gillen et al. 1984; Bailey et al. 1996). Across our study meadows, $75.1 \%$ of total camera days had no cows present. Many of the grazed meadows had very low MMDH, with only a few meadows accounting for the majority of marks both years. Although we did not conduct a study of cow presence in meadows versus surrounding forest, we can conclude that in our study cows were not present much of the time during daylight hours.

We found a range of cattle marks across the nine study meadows, but overall, images were dispersed throughout the season except at Back Badger meadow (FWA). This site is adjacent to the road where cattle turn out at the beginning of the season, and cameras reflected the higher cattle presence early season close to where the cattle entered the allotment. This corresponds to Gillen et al. (1985), who saw an increase in cattle early season in areas close to a turn-out point.

Several studies have used different techniques to identify diurnal cattle grazing patterns, and results are varied (e.g., Roath and Krueger 1982; Gillen et al. 1985; Harris 2001; Parsons et al. 2003). For example, Roath and Krueger (1982) found that most grazing started at sunrise and lasted for 
Table 6. Deer marks normalized by day and area using the same days and camera area used in Tables 3 and 4.

\begin{tabular}{|c|c|c|c|c|}
\hline \multirow[b]{2}{*}{ Camera } & \multicolumn{2}{|c|}{ Total marks } & \multicolumn{2}{|c|}{ Mean marks per day per ha } \\
\hline & 2006 & 2007 & 2006 & 2007 \\
\hline \multicolumn{5}{|l|}{ Fence wet area } \\
\hline Back Badger_1 (inside) & 14 & 0 & 1.2 & 0.0 \\
\hline Back Badger_1 (outside) & 0 & 0 & 0.0 & 0.0 \\
\hline Back Badger_2 (outside) & 0 & 0 & 0.0 & 0.0 \\
\hline Continental_1 (inside) & 7 & 13 & 0.5 & 0.6 \\
\hline Continental_2 (outside) & 3 & 59 & 0.9 & 8.5 \\
\hline Exchequer_1 (inside) & 12 & 14 & 0.7 & 0.5 \\
\hline Exchequer_2 (outside) & 3 & 0 & 1.3 & 0.0 \\
\hline \multicolumn{5}{|l|}{ Fence whole meadow } \\
\hline Bear Paw & 37 & 440 & 1.7 & 13.0 \\
\hline Mono & 120 & 5 & 5.6 & 0.2 \\
\hline Swainson's Thrush & 21 & 18 & 1.4 & 1.1 \\
\hline \multicolumn{5}{|l|}{ Standard grazing } \\
\hline Cabin_1 & 0 & 3 & 0.0 & 0.3 \\
\hline Cabin_2 & 5 & 0 & 0.7 & 0.0 \\
\hline Cabin_3 & 13 & 9 & 1.4 & 1.0 \\
\hline Hash_1 & 3 & 8 & 0.8 & 0.9 \\
\hline Hash_2 & 10 & 7 & 0.7 & 0.3 \\
\hline Hash_3 & 40 & 7 & 1.6 & 0.3 \\
\hline Marigold_1 & 1 & 3 & 0.1 & 0.1 \\
\hline Marigold_2 & 1 & 0 & 0.5 & 0.0 \\
\hline Marigold_3 & 41 & 12 & 2.4 & 0.6 \\
\hline
\end{tabular}

approximately 3 hours. They also found "lethargic grazing" by a few individuals mid-day, more active grazing from late afternoon until sunset, and cattle bedding down from dark until sunrise. Conversely, Harris (2001) found that cows grazed for a total of 8.2 hours per day, with 6.3 hours during daylight and

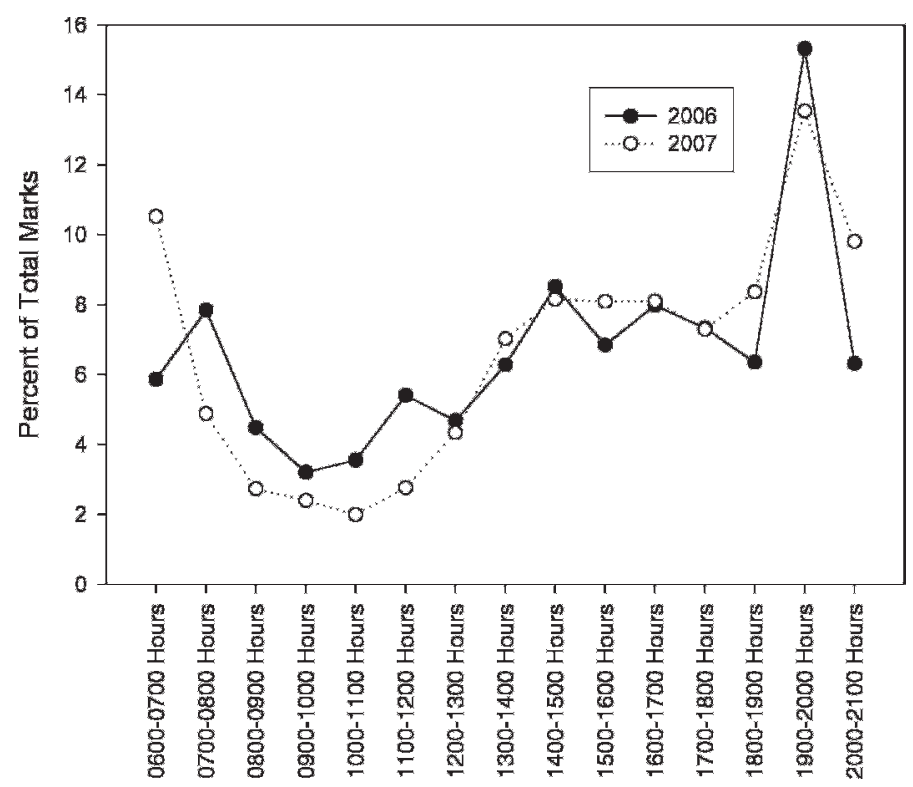

Figure 2. Diurnal cattle grazing patterns for 2006 and 2007. All cameras with marks were included in the analysis $(n=12$ for 2006 and $n=15$ for 2007).

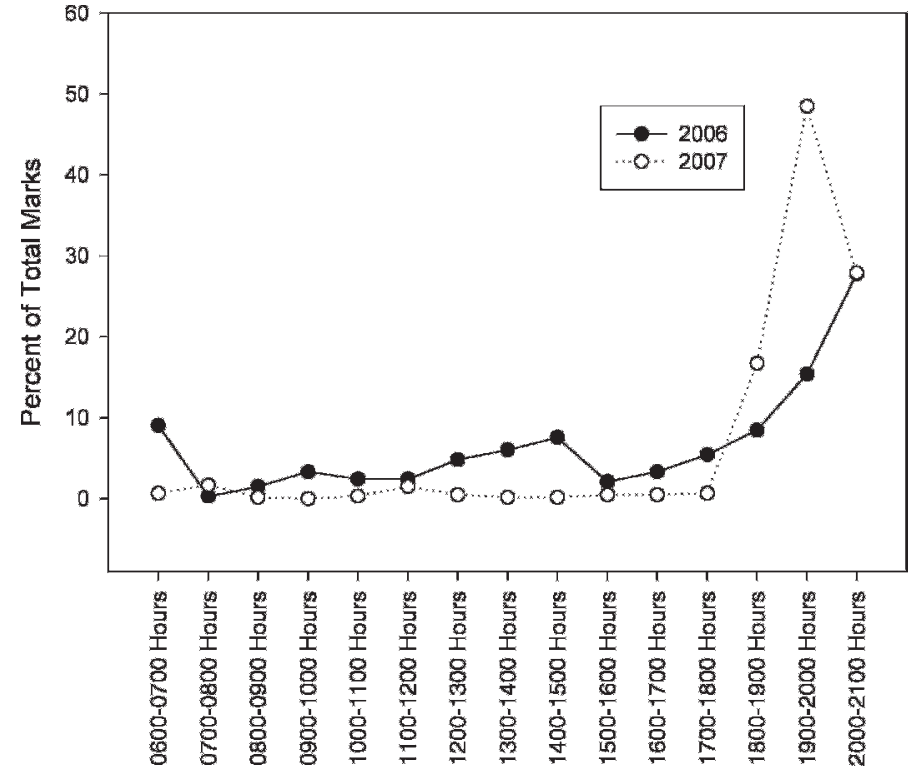

Figure 3. Diurnal deer grazing patterns for 2006 and 2007. All cameras with marks were included in the analysis ( $n=12$ for 2006 and $n=15$ for 2007).

the remainder occurring at night. We found cattle dispersed throughout daylight hours, but higher presence in the morning and evening corresponds with other studies. Because the cameras did not monitor cattle use during the night, we were unable to draw conclusions about grazing during the rest of the day.

\section{Meadow Fencing}

We confirmed the problems of partial meadow fencing, with the areas outside fences at Back Badger and Exchequer meadows having high MMDH both seasons even with less available grazing area compared to SG meadows (Tables 3 and 4). Research has shown that cattle retain information about important factors such as the location of water, shade, and feeding sites (Bailey 1995; Bailey et al. 1996), and cattle returned to these meadows both years regardless of the reduced available forage. It is reasonable that cattle would return to Back Badger because it is close to the cattle turn-out point, has a stream adjacent to it, and other meadows are nearby with available forage. There is also a stream in Exchequer meadow, large patches of Carex nebrascensis and Carex utriculata, and many shaded areas outside the fenced portion of the meadow. The smaller areas did not appear to deter animal use, but instead concentrated it.

We also recorded a number of cattle within fences at Back Badger both years and at Bear Paw in 2007; the utilization values recorded for these areas (Mcllroy 2008) reflect this cattle presence. Grazing treatments are often vague, with studies citing "heavy" and "light" levels and noting fencing treatments

Table 7. Mean ( $\pm 1 \mathrm{SE})$ marks per day per ha for cattle and deer by treatment.

\begin{tabular}{lcccc}
\hline & $\begin{array}{c}\text { FWA_In } \\
(n=6)\end{array}$ & $\begin{array}{c}\text { FWA_Out } \\
(n=8)\end{array}$ & $\begin{array}{c}\text { Fence whole } \\
\text { meadow }(n=6)\end{array}$ & $\begin{array}{c}\text { Standard grazing } \\
(n=18)\end{array}$ \\
\hline Cattle & $4.8(3.7)$ & $114.6(27.2)$ & $3.0(3.0)$ & $65.8(16.3)$ \\
Deer & $0.6(0.2)$ & $1.3(1.0)$ & $3.8(2.0)$ & $0.7(0.1)$ \\
\hline
\end{tabular}


but not quantifying actual use across treatments. This study highlights the importance of measuring and reporting utilization of treatments due to the wide variation that we documented and the level of trespass that cameras captured inside fences.

\section{Cattle and Deer Interactions}

Several studies have shown direct forage and habitat competition between cattle and mule deer (Dasman 1949; Loft 1988; Kie et al. 1991; see Chaikina and Ruckstuhl 2006 for review). For example, Loft (1988) conducted research on the Stanislaus National Forest, California, and found that female mule deer remained in generally the same area with cattle grazing, but that home range estimates were $18 \%$ larger with moderate cattle grazing and $41 \%$ larger with heavy grazing. Additionally, Kie et al. (1991) conducted a study in the McCormick Creek Basin of the Sierra Nevada and found that deer spent more time feeding and less time resting with increased stocking rates. However, another study in the Chopaka Mountains, Washington, found a small overlap $(15 \%)$ in mule deer and cattle diets (Campbell and Johnson 1983). Furthermore, Stewart et al. (2003) used stable isotopes from fecal samples of cattle, elk, and mule deer and showed significant differences in diets of these three species. Vavra and Sheehy (1996) argued that cattle improve forage for deer grazing by removing the previous year's growth and thereby increasing the protein content of the current year's forage.

In this study, deer MMDH did not differ significantly based on fenced versus nonfenced areas. In fact, although there were nearly three times more deer in the FWM treatment compared to any other, the second highest occurrence of deer was in the FWA_Out areas, where cows were most prevalent. Further, the majority of marks occurred at a few meadows both years, inferring that it is habitat preference or other factors that determine deer grazing and not presence or absence of cattle. However, one interesting observation is that of the more than 409000 images reviewed we noted only one image with both a cow and a deer present at the same time. This corresponds with Loft et al. (1993) and Stewart et al. (2002) who both reported that mule deer avoided cattle when present.

\section{Cameras for Meadow Monitoring}

Our third objective was to assess the effectiveness of cameras for monitoring cattle use in meadows. After two years of data collection and analysis, we found digital cameras to be useful in identifying presence and distribution of cattle grazing, but we do not think that they are viable tools for monitoring meadows. First of all, monitoring with digital cameras is much more expensive and requires significantly more time than other currently used methods such as measuring late season utilization and recording plant composition data. Time required for camera placement and maintenance was nominal, with each camera taking about two hours to install and then one hour each month to replace batteries and download images. However, travel time increases these estimates, and the requirement to replace batteries monthly involves at least two additional trips per grazing season. Furthermore, image review and data analysis required several weeks following both seasons. There was therefore a significant labor cost and initial investment was \$1200 per camera, undoubtedly making cameras cost prohibitive for many management programs.
Locke et al. (2005) also found that their web-based system for monitoring wildlife in the Chihuahuan Desert, Texas, was expensive, with a total cost of $\$ 12000$. However, Yasuda and Kawakami (2002) developed a web-based system for monitoring wildlife in the Tama Forest (Japan) that cost approximately $\$ 550$, but their technique would not have been effective for our project as the area captured by each camera was significantly smaller and not comparable concerning image size and review.

Regardless of cost, we were unable to identify animal behavior such as grazing or resting for animals further from the cameras. This could be addressed by capturing smaller areas if additional information is desired about cattle grazing patterns, but much research on animal behavior has been conducted (see Harris et al. 2002; George 2003; Parsons et al. 2003). Due to the fact that we were unable to conclude how long cattle were grazing versus resting we have presence/absence data instead of a more meaningful metric of cattle use. Also, the variation in marks among both cameras and meadows made scaling to a larger landscape level unreasonable. Last, managers have inquired about using cameras for monitoring other meadow activities such as off-road vehicle (ORV) trespass. We found face identification difficult unless a person was very close to the camera, and we were unable to capture ORV trespass that occurred in 2006 and 2007 at Back Badger meadow. Instead, we recorded images with tire marks, confirming that trespass had occurred but with no data to aid in identifying the culprit(s). One scenario where cameras could be effective is in smaller areas where managers wanted to restrict or monitor any use.

\section{IMPLICATIONS}

Montane meadows in the Sierra Nevada Range offer unique habitat within forested landscapes, provide forage for grazing animals, and serve as the headwaters to numerous streams and rivers that supply water to California. Managing grazing in montane meadows is a complex and often contentious issue, and this study aimed to contribute data about real-time animal presence in meadows, identify the effects of fencing treatment on animal distribution, and test digital photography as a tool for monitoring cattle. We found variable seasonal grazing over both years but more consistent diurnal patterns between seasons. Fencing treatments affected the distribution of both cattle and deer, but there was no statistically significant difference. We did identify repeated cattle trespass within fences, which confirms for managers the problems with fencing meadows as a means to restrict cattle grazing and emphasizes the challenges of managing public lands with multiple resource objectives. Furthermore, we found very different cattle presence within meadows and among treatments, highlighting the need to quantify utilization at the meadow scale to effectively measure animal use. Continuing to explore means of meadow management and monitoring is imperative for the longterm conservation of these important systems.

\section{ACKNOWLEDGMENTS}

We would like to thank members of the Allen-Diaz Lab at UC Berkeley, particularly Ling He and Jennifer McGarvey, for field assistance and image reviewing. Jason Kreitler provided GIS support and Bill Frost, Neil McDougald, and Ken Tate offered thoughtful input for this research. 


\section{LITERATURE CITED}

ArcGIS [computer program]. 2006. Version 9.2. Redlands, CA, USA: ESRI Inc.

BAILEY, D. W. 1995. Daily selection of feeding areas by cattle in homogeneous and heterogeneous environments. Applied Animal Behavior Science 45:183-199.

Balley, D. W., J. E. Gross, E. A. Laca, L. R. Rittenhouse, M. B. Coughenour, D. M. Swift, AND P. L. Sims. 1996. Mechanisms that result in large herbivore grazing distribution patterns. Journal of Range Management 49:386-400.

Boyd, C. S., K. T. Hopkins, and T. J. SveJCAR. 2006. A photo-based monitoring technique for willow communities. Wildlife Society Bulletin 34:1049-1053.

Boyd, C. S., and T. J. Svejcar. 2005. A visual obstruction technique for photo monitoring of willow clumps. Rangeland Ecology \& Management 58:434-438.

Bryant, L. D. 1982. Response of cattle to riparian zone exclusion. Journal of Range Management 35:780-785.

Campbell, E. G., and R. L. Johnson. 1983. Food habitats of mountain goats, mule deer, and cattle on Chopaka Mountain, Washington, 1977-1980. Journal of Range Management 36:488-491.

Chaikina, N. A., and K. E. RuckstuHL. 2006. The effect of cattle grazing on native ungulates: the good, the bad, and the ugly. Rangelands 28:8-14.

Daly, C., W. P. Gibson, G. H. Taylor, G. L. Johnson, and P. Pasteris. 2002. A knowledge-based approach to the statistical mapping of climate. Climate Research 22:99-113.

Dasmann, W. P. 1949. Deer-livestock forage studies on the interstate winter deer range in California. Journal of Range Management 2:206-212.

Field, C. B., G. C. Daily, F. W. Davis, S. Gaines, P. A. Matson, J. Melack, and N. L. MıLLeR. 1999. Confronting climate change in California: ecological impacts on the Golden State. Cambridge, MA, USA: Union of Concerned Scientists and the Ecological Society of Americ. $63 \mathrm{p}$.

George, M. 2003. Cows in space. Davis, CA, USA: Sierra Foothill Research and Extension Center, University of California. $2 p$.

George, M., D. C. Ganskopp, D. Balley, M. Borman, G. Surber, and N. Harris. 2007. Factors and practices that influence cattle distribution. Davis, CA, USA: University of California Division of Agriculture and Natural Resources. Rangeland Management Series, Publication 8217. 20 p.

Gillen, R. L., W. C. Krueger, and R. F. Miller. 1984. Cattle distribution on mountain rangeland in Northeastern Oregon. Journal of Range Management 37:549-553.

Gillen, R. L., W. C. Krueger, and R. F. Miller. 1985. Cattle use of riparian meadows in the Blue Mountains of Northeastern Oregon. Journal of Range Management 38:205-209.

HarRIS, N. R. 2001. Cattle behavior and distribution on the San Joaquin Experimental Range in the foothills of Central California [dissertation]. Corvallis, OR, USA: Oregon State University. 199 p.

Harris, N. R., D. E. Johnson, M. R. George, and N. K. McDougald. 2002. The effect of topography, vegetation, and weather on cattle distribution at the San Joaquin Experimental Range, California. Albany, CA, USA: US Department of Agriculture Forest Service General Technical Report PSW-GTR-184. p. 53-63.

Hayes, G. F., AND K. D. Holl. 2003. Cattle grazing impacts on annual forbs and vegetation in mesic grasslands in California. Conservation Biology 17:1694-1702.

Hickman, J. C. [ED.]. 1993. The Jepson manual-higher plants of California. Berkeley, California, USA: University of California Press.

Hickman, K. R., D. C. Hartnett, R. C. Cochran, and C. E. Owensby. 2004. Grazing management effects on plant species diversity in tallgrass prairie. Journal of Range Management 57:58-65.

HookeR, S. K., I. L. Boyd, AND M. JeSSOPp. 2002. Monitoring the prey-field of marine predators: combining digital imaging with datalogging tags. Marine Mammal Science 18:680-697.

Kattleman, R., and M. Embury. 1996. Riparian areas and wetlands. In: Status of the Sierra Nevada, Sierra Nevada ecosystem project: final report to Congress. Davis, CA, USA: Center for Water and Wildland Resources, University of California, Davis, Vol. III, p. 201-267.

Kie, J. G., C. J. Evans, E. R. Loft, And J. W. Menke. 1991. Foraging behavior by mule deer: the influence of cattle grazing. Journal of Wildlife Management 55:665-674.

KIE, J. G., AND S. A. Myler. 1987. Use of fertilization and grazing exclosures in mitigating lost meadow production in the Sierra Nevada, California, USA. Environmental Management 11:641-648.
Koerth, B. H., and J. C. Kroll. 2000. Bait type and timing for deer counts using cameras triggered by infrared monitors. Wildlife Society Bulletin 28:630-635.

Locke, S. L., M. D. Cline, D. L. Wetzel, M. T. Pittman, C. E. Brewer, and L. A. Harveson. 2005. From the field: a web-based digital camera for monitoring remote wildlife. Wildlife Society Bulletin 33:761-765.

LoFT, E. R. 1988. Habitat and spatial relationships between mule deer and cattle in a Sierra Nevada forest zone [dissertation]. Davis, CA, USA: University of California, Davis. 144 p.

Loft, E. R., J. G. KIE, AND J. W. Menke. 1993. Grazing in the Sierra Nevada: home range and space use patterns of mule deer as influenced by cattle. California Fish and Game 79:145-166.

Loft, E. R., J. W. Menke, and J. G. Kie. 1991. Habitat shifts by mule deer: the influence of cattle grazing. Journal of Wildlife Management 55:16-26.

Loomis, J. B., E. R. Loft, D. R. UpdiKe, AND J. G. KIE. 1991. Cattle-deer interactions in the Sierra Nevada: a bioeconomic approach. Journal of Range Management 44:395-398.

LOPEZ, R. R., AND N. J. SILVy. 1999. Use of infrared-triggered cameras and monitors in aquatic environments. Proceedings of the Annual Conference of the Southeastern Association of Fish and Wildlife Agencies 53:200-203.

MATLAB [computer program]. 2005. Version 7. 1. Natick, MA, USA: Mathworks.

MclıRoY, S. K. 2008. Identifying ecological patterns and processes in montane meadows of the Sierra Nevada Range [dissertation]. Berkeley, CA, USA: University of California, Berkeley. $117 \mathrm{p}$.

McMahan, C. A., and C. W. Ramsey. 1965. Response of deer and livestock to controlled grazing in central Texas. Journal of Range Management 18:1-7.

Mitsch, W. J., AND J. G. Gosselink. 1993. Wetlands. New York, NY, USA: Van Nostrand Reinhold. 722 p.

Mueller-Dombais, D., and H. Ellenberg. 1974. Aims and methods of vegetation ecology. New York, NY, USA: John Wiley and Sons. 547 p.

Ng, S. J., J. W. Dole, R. M. Sauvajot, S. P. D. Riley, and T. J. Valone. 2004. Use of highway undercrossings by wildlife in southern California. Biological Conservation 115:499-507.

Parsons, C. T., P. A. Momont, T. Delcurto, M. Mclnnis, and M. Porath. 2003. Cattle distribution patterns and vegetation use in mountain riparian areas. Journal of Range Management 56:334-341.

RatlifF, R. D. 1985. Meadows in the Sierra Nevada of California: state of knowledge. Berkeley, CA, USA: US Department of Agriculture, Forest Service, Report PSW-84. 16 p.

Roath, L. R., and W. C. Krueger. 1982. Cattle grazing and behavior on a forested range. Journal of Range Management 35:332-338.

Robins, J. D., and J. E. Vollmar. 2002. Livestock grazing and vernal pools. In: Vollmar, J. E. [ED.]. Wildlife and rare plant ecology of eastern Merced County's vernal pool grasslands. Berkeley, CA, USA: Vollmar Consulting. p. 401-430.

Sanders, S. D., And M. A. FleEtr. 1989. Montane riparian habitat and willow flycatchers: threats to a sensitive environment and species. Berkeley, CA, USA: US Department of Agriculture, Forest Service, Report PSW-110. p. 262-266.

SPLUS [computer program]. 2005. Version 7.0. Palo Alto, CA, USA: TIBCO Software.

Stewart, K. M., R. T. Bowyer, J. G. Kie, N. J. Cimon, and B. K. Johnson. 2002. Temporospatial distributions of elk, mule deer, and cattle: resource partitioning and competitive displacement. Journal of Mammalogy 83:229-244.

Stewart, K. M., R. T. Bowyer, J. G. Kie, B. L. Dick, and M. Ben-David. 2003. Niche partitioning among mule deer, elk, and cattle: do stable isotopes reflect dietary niche? EcoScience 10:297-302.

Stover, S. L. 1985. Silviculture and grazing in the New Forest: rival land uses over nine centuries. Journal of Forest History 29:32-42.

US Department of Agriculture, Forest Service. 2004. Sierra Nevada forest plan amendment: final supplemental environmental impact statement and record of decision. Berkeley, CA, USA: US Department of Agriculture, Report R5-MB046. $492 \mathrm{p}$.

Vavra, M., And D. P. Sheehy. 1996. Improving elk habitat characteristics with livestock grazing. Rangelands 18:182-185.

YASUDA, M., AND K. KaWAKAMI. 2002. New method of monitoring remote wildlife via the Internet. Ecological Research 17:119-124. 